\title{
The Impact of Climate Factors, Disaster, and Social Community in Rural Development
}

\author{
Faradiba FARADIBA ${ }^{1}$, Lodewik ZET ${ }^{2}$
}

Received: June 15, 2020 Revised: July 12, 2020 Accepted: August 10, 2020

\begin{abstract}
Global warming affects climate change and has an overall impact on all aspects of life. On the other hand, community behavior and disaster aspects also have an important role in people's lives. This will also have an impact on regional development. This study aims to find the effect of climate, disaster, and social community on rural development. This study uses data on the potential of rural development from PODES 2014, and 2018 data collection on climate conditions and regional status is sourced from relevant ministries. This research uses Ordinary Least Square (OLS) Regression Analysis method, then continued with CHAID analysis to find the segmentation of the role of climate, disaster, and social factors on rural development. The results of this study found that all research regressor variables significantly influence the Rural Development Index (IPD2018), with an R-squared value of 32.9 percent. Efforts need to be taken in order to implement policies that are targeted, effective, and efficient. The results of this study can be a reference for the government in determining policies by focusing on rural development that have high duration of sunshine, cultivating natural disaster warnings, especially in areas prone to natural disasters, and need to focus on underdeveloped areas.
\end{abstract}

Keywords: Climate, Natural Disasters, Rural Development, CHAID, Development Policy

JEL Classification Code: F63, F64, O22, Q56, R58

\section{Introduction}

At present, the world is faced with the issue of global warming. The issue has an impact on climate change that is felt by humans. In some regions, climate change will have an impact on all aspects of life (Han et al., 2016; Sarkodie \& Strezov, 2019; Sadeka et al., 2020; Filho et al., 2020; Castells-Quintana et al., 2018; Walker et al., 2019; Olayide \& Alabi, 2018). In addition, extreme climate change will have a derivative impact such as natural disasters and changes in

${ }^{1}$ First Author and Corresponding Author. Associate Professor, Physics Education Study Programme, Faculty of Teacher Training and Education, Indonesian Christian University, Indonesia [Postal Address; JI. Mayjen Sutoyo No 2. Jakarta 13630 - Indonesia] Email: faradiba@uki.ac.id

${ }^{2}$ Postgraduate Program in Development Economics, Faculty of Economics and Business, Gadjah Mada University, Indonesia. Email: lodewikzet@mail.ugm.ac.id

() Copyright: The Author(s)

This is an Open Access article distributed under the terms of the Creative Commons Attribution Non-Commercial License (https://creativecommons.org/licenses/by-nc/4.0/) which permits unrestricted non-commercial use, distribution, and reproduction in any medium, provided the original work is properly cited. the livelihoods of local communities. So that, in the long run. climate change, disaster, and community behavior will have an impact on people's welfare (Sørensen, 2018). The accumulation of community welfare, as a micro community, can be reflected through rural development (Biegańska et al., 2018; Xie, 2020).

The high climate change can also impact on the economic development of a region (Barbier \& Hochard, 2018; Tanure et al., 2020; Stern, 2018; Moreno-Cruz \& Smulders, 2018). In addition, extreme climate change can cause natural disasters, which is one of the obstacles to the development of the business world (Deligne et al., 2017; Padli et al., 2018; Li et al., 2020). This condition will certainly affect the interests of investors (Xuan, 2020). In addition, the mitigation of poor disaster management will also have an impact on the lack of investment in the local area, so that it will have an impact on regional income per capita (Bronfman et al., 2019; Sulistyaningrum et al., 2018; Jha, 2017). This condition is exacerbated when rural population is far from the center of the crowd (Nørgaard \& Thuesen, 2020).

Rural regulations define development in rural areas as "efforts to improve the quality of life and life for the greatest welfare of rural communities". Article 78 paragraph 
(1) states that the development goals in rural areas means "improving the welfare of the rural community and the quality of human life and poverty reduction through meeting basic needs, construction of rural facilities and infrastructure, development of local economic potential, and use of natural resources and environmentally sustainable". "In the implementation of rural development it is important to prioritize togetherness, kinship, and mutual cooperation to realize the mainstreaming of peace and social justice", it is stated in article 78 paragraph (3).

Factors that can become obstacles to development performance are through natural disasters that often occur in an area (Zhang \& Managi, 2020; Sawada \& Takasaki, 2017; Straub et al., 2020; Jackson et al., 2020; Jiang et al., 2016). Development will be in vain, if an area prone to natural disasters does not pay attention to the condition of the area and the potential for disaster. On the other hand, even areas of concern for potential disasters will still have various unavoidable limitations so that development acceleration will not be effective (Imperiale \& Vanclay, 2016; Fang et al., 2018; Banerjee \& Hysjulien, 2018).

Climate change will certainly change the social conditions that exist in society, as reflected in changes in livelihoods (Arronson \& Schöb, 2018). The sector most affected by climate change is the agricultural sector (Faradiba, 2018; Javed et al., 2020, Soubry et al., 2020; Sousa et al., 2018; Falco et al., 2019). The agricultural sector is the sector most expected to develop along with population growth (KirylukDryjska et al., 2020; Juhola, 2017; Abid et al., 2016; Osborne \& Nick, 2019; Chriest \& Niles, 2018). Sometimes, people are required to engage in various ways to support agricultural production (Gatto et al., 2017). However, sometimes these methods actually exacerbate the climatic conditions of an area, and farmers did apparently not realize it. For example, to grow crops, sometimes people are willing to burn fields. Farmers feel this is more effective and efficient method. In fact, puffs of smoke from burning fields will damage the ozone layer and will indirectly affect climate change. Especially, if an area is around the equator, which tends to has a tropical climate. On the other hand, through PODES data, there are areas where mangrove forests exist when an area is around the sea. This is very positive for the region, considering that the coastal area is one of the areas that are vulnerable to natural disasters.

Indonesia has a lot of mineral resources. However, based on research conducted by Nazir et al., (2020), it is suggested that the management of these resources sometimes has positive and negative impacts. On the one hand, it will improve the mining and quarrying sector; on the other hand, it will damage the environment because of the excavation sites in the forest, which is the lung of the local area. Forests that continue to be cut down due to exploration of natural resources, will have an impact on the climate that occurs (Mancini \& Sala, 2018).
There have been many studies that examine the relationship of climate, natural disasters, and social conditions to economic conditions at the state or provincial level (Bergholt \& Lujala, 2012; Tang et al., 2019; Narayan, 2002). However, no one has analyzed the influence of climate, disaster and community behavior on development at the rural level. Therefore, the expected results in this study are to find the effect of climate factors, disasters, and community behavior on rural development in Indonesia. The results of this study describe the regressor as having a significant effect on rural development. Our research uses 21 variables: rainfall, wind speed, humidity, temperature, air pressure, duration of sunshine, burning fields, excavation sites, warnings of natural disasters, floods, flash floods, earthquakes, whirlwinds, volcanoes, and a number of control variables that also affect rural development. This research will review as well what indicators need to be the focus of attention so that rural development is improved.

\section{Literature Review}

Based on the introduction, there are several factors that influence rural development when viewed from the aspects of climate, disaster and community behavior. When these aspects can be anticipated and controlled properly, it will result in regional development that can run as expected. The impact on rural development will go according to plan and will produce prosperity and comfort for the community (Austin et al., 2020).

Climate change is a change in the average weather over a relatively long period. In modern terms, climate change is also known as global warming, which causes an increase of geothermal heat. The heat tends to be felt by the people in the area across the equator. Indonesia is one of the countries in the world that is crossed by the equator. Phenomena that occur around the equator, including sunlight in the equatorial region, fell to the ground at an angle of 90 degrees. This angle of falling sunlight makes solar power falling per unit area larger, so that the area around the equator is hotter. Sunlight is almost always located above the equator, so temperatures below the equator are always high.

Climate has an influence in the economic development, both directly and indirectly. It has a direct effect when the livelihood of residents in an area relies on climate factors. Communities cannot generate income when climate change occurs. It has an indirect effect when there is an intermediate event before it impacts on people's income. For example, due to the high rainy season, an area is flooded. Floods that occurred in the region will disrupt the economic activities of the community (Krawchenko et al., 2016; Sapkota et al., 2016). Climatic conditions in each region can be different, so the economic progress of the impact of the climate will also be different. 
Inequalities that occur in an area, can be divided into developed regions and developing regions, so this will trigger social inequality (Hulme \& Turner, 1990; Iek \& Blesia, 2019). One reason that causes disparities in rural and urban areas is the development of economic activities that occur in society (urban bias). As a result of this phenomenon, the sector most affected in the rural economy is the agricultural sector. Contrary to the agriculture sector, the industrial and service sectors tend to develop more. Each country has alternative steps to overcome the disparities that occur between regions, with a focus on rural area development, because disparities between regions can cause poverty. Based on research conducted by Uthes et al. (2017), rural development that is still lagging behind is a step that needs to be taken in developing rural areas by considering socio-economic conditions and community limitations. Through these steps it is hoped that the quality of life in the underdeveloped rural areas can improve, or at least be not much different from other rural areas (Puspasari \& Koswara, 2016; Stojcheska et al., 2016). In national development, Indonesia has identified disadvantaged districts. This is intended so that there is more efforts from the authorities in developing these areas.

Rural communities tend to be difficult to accept the changing era. This has an impact on the modernization of economic activity that is normally carried out by the community (Li et al., 2018). Even though maintaining the culture is very important, we need to also adopt an outside culture that is constructive and does not conflict with customary norms. Rural communities tend to accept conditions, so do not have a strong motivation to change the strata of life. In addition, rural communities have a natural way, which tends to be quickly satisfied with what is obtained, even though the rural area has a lot of potential that has not been fully developed. Because of these factors, triggering development needs to be focused on rural areas (Berdegue \& Soloaga, 2018).

Development in rural areas needs to be done to support the economy of the region and, by extension, of the country. In addition, development is taking place in rural areas as an effort to reduce poverty and reduce rural inequality. In practice, rural development can be a source of economic growth driven into the countryside, so that rural areas become more attractive places to live and as a source of income. Another important factor is rural infrastructure. Infrastructure must be provided as a medium for development activities, so that rural areas can become more advanced and developed.

Indonesia is one of the largest archipelagic countries in the world with around 17,491 islands. The Indonesian archipelago spreads around the equator, and tends to have tropical weather. Indonesian territory is limited by administrative areas, which have very strategic functions. Some of its functions include the separation of administrative territory; besides that, the administrative area also functions as a determinant of all regional development activities and the calculation of regional income sources (PAD). This is stated in "Guidelines for asserting regional boundaries have been established by the government through Permendagri No. 1 of 2006". The administrative area level II consists of districts and urban areas. Urban areas tend to be more advanced in terms of development.

\section{Research Methods and Materials}

This study uses PODES2014 data (Rural Potential) collected by BPS-Statistics Indonesia, as an independent variable, and the Rural Development Index 2018, which has been calculated by BPS-Statistics Indonesia, as the dependent variable. Between the independent and dependent variables, the data are distinguished so that it is visible. The number of observations used was 72,333 from rural areas. This figure is the result of matching the 2014 PODES Variable with the 2018 Rural Development Index. In addition, this study uses district/municipality per capita GRDP data sourced from BPS-Statistics Indonesia, underdeveloped areas as stated in "Presidential Regulation Number 131 Year 2015 Regarding Determination of Disadvantaged Areas in 20152019", and climate average data for 2001-2014 sourced from BMKG- Meteorology Climatology and Geophysics Council. In addition to climate variables, the independent variables use dummy variables related to the existence/status of the corresponding conditions - code " 1 " if the rural area has conditions that correspond to the observation variable, and code " 0 " if vice versa. We used OLS multiple regression analysis tools, and continued with Chi-squared Automatic Interaction Detector (CHAID) analysis to find climate segmentation, disaster, and community behavior towards rural development.

$$
\begin{aligned}
Y=\alpha & +\beta_{1} X_{\text {rainfall }}+\beta_{2} X_{\text {windspeed }} \\
& +\beta_{3} X_{\text {humidity }}+\beta_{4} X_{\text {temperature }} \\
& +\beta_{5} X_{\text {airpressure }}+\beta_{6} X_{\text {duratino of sunshine }} \\
& +\beta_{7} X_{\text {burning fields }}+\beta_{8} X_{\text {excavation sites }} \\
& +\beta_{9} X_{\text {warning disaster }}+\beta_{10} X_{\text {floods }}+\beta_{11} X_{\text {flash floods }} \\
& +\beta_{12} X_{\text {earthquake }}+\beta_{13} X_{\text {whirlwinds }} \\
& +\beta_{14} X_{\text {volcanoes }}+\beta_{15} X_{\text {borderbythesea }} \\
& +\beta_{16} X_{\text {manggroveforest }}+\beta_{17} X_{\text {underdevelopedarea }} \\
& +\beta_{18} X_{\text {grdpcaptia }}+\beta_{19} X_{\text {regional status }} \\
& +\beta_{20} X_{\text {equatorprovince }}+\beta_{21} X_{\text {equatorregency }}+\varepsilon
\end{aligned}
$$

The Rural Development Index (IPD) is an index compiled to measure performance or development that occurs in rural areas. IPD is arranged through variables that can represent 
the development that occurs. IPD is one alternative to show the conditions of rural development, because this index accommodates five dimensions and 42 indicators that describe the availability and accessibility of services to rural communities. The calculation of IPD in 2018 uses the results of the 2018 Rural Potential Data Collection (BPS, 2019).

Next, the analysis used the Chi-squared Automatic Interaction Detector (CHAID). CHAID generally estimates a single variable, referred to as regresan, which is associated with other variables, called a regressor. CHAID is an iterative technique that tests one by one the regressors used in the classification, and arranges them based on the level of statistical significance of Chi-square on regresan (Gallagher, 2000). CHAID analysis is expected to be able to give an indicator of priority for conducting rural development. This test technique allows us to find out the independence between two variables at each level. For example, a first variable has $r$ categories and the second variable has $c$ categories, then $n_{i j}$ is an observation on the first variable at level $i$ and the second variable at level $j$, presented in the table below:

where

pij is the probability of the occurrence of the slice between row $i$ and column $j$

$p_{i}$ is the total probability on the row $i$ $p_{\bullet i}$ is the total probability on the columns $j$

The hypothesis in chi-square testing is:

$H_{0}: p_{i j}=p_{i \cdot} p_{\cdot j}$ (no relationship between rows and columns (independent))

$H_{1}: p_{i j} \neq p_{i \cdot} p_{\cdot j}$ (there is a relationship between rows and columns (dependent))

Whereas the test statistic is:

$$
\begin{aligned}
& \chi^{2}=\sum_{i=1}^{r} \sum_{j=1}^{c} \frac{\left(n_{i j}-E_{i j}\right)^{2}}{E_{i j}} \\
& \chi^{2}=\frac{n_{i \bullet} n_{\bullet j}}{n}
\end{aligned}
$$

where

$n_{i j}=$ the number of observations in the row $i$ and column $j$

$E_{i j}=$ Expectation value of observations in the row $i$ and column $j$

$n_{i \cdot}=$ total number of observations in row $i$

$n_{\cdot j}=$ the total number of observations in the row $j$

$n=$ total number of respondents

The decision taken from this chi-square test is rejected $H_{0}$ if value of $\chi^{2}$ count $>\chi^{2}$ table or $p$-value $<\alpha$.

\begin{tabular}{|c|c|c|c|c|c|}
\hline Row and Column & 1 & 2 & $\ldots \ldots$ & C & Total \\
\hline 1 & $n_{11}$ & $n_{12}$ & $\ldots \ldots$ & $n_{1 \mathrm{c}}$ & $n_{1}$ \\
\hline 2 & $n_{21}$ & $n_{22}$ & $\ldots \ldots$ & $n_{2 c}$ & $n_{2 .}$ \\
\hline$\cdots$ & $\ldots \ldots$ & $\ldots \ldots$ & $\ldots \ldots$ & $\ldots \ldots$ & $\ldots \ldots$ \\
\hline$\ldots$ & $\cdots \cdots$ & $\ldots \ldots$ & $\ldots \ldots$ & $\ldots \ldots$ & $\ldots \ldots$ \\
\hline$\cdots$ & $\ldots \ldots$ & $\ldots \ldots$ & $\ldots \ldots$ & $\ldots \ldots$ & $\ldots \ldots$ \\
\hline$r$ & $n_{\mathrm{r} 1}$ & $n_{\mathrm{r} 2}$ & $\ldots \ldots$ & $n_{\mathrm{rc}}$ & $n_{\mathrm{r} \bullet}$ \\
\hline Total & $n_{\cdot 1}$ & $n_{.2}$ & $\ldots \ldots$ & $n_{\text {.c }}$ & $n$ \\
\hline
\end{tabular}

Table 1: Chi-Square Test Data Structure

\begin{tabular}{|c|c|c|c|c|c|}
\hline Row and Column & 1 & 2 & $\ldots . .$. & C & Total \\
\hline 1 & $p_{11}$ & $p_{12}$ & $\ldots \ldots$ & $p_{1 \mathrm{c}}$ & $p_{1 .}$ \\
\hline 2 & $p_{21}$ & $p_{22}$ & $\ldots \ldots$ & $p_{2 c}$ & $p_{2}$ \\
\hline$\ldots$ & $\ldots \ldots$ & $\ldots \ldots$ & $\ldots \ldots$ & $\ldots \ldots$ & $\ldots \ldots$ \\
\hline$\ldots$ & $\ldots \ldots$ & $\ldots \ldots$ & $\ldots \ldots$ & $\ldots \ldots$ & $\ldots \ldots$ \\
\hline$\ldots$ & $\ldots \ldots$ & $\ldots \ldots$ & $\ldots \ldots$ & $\ldots \ldots$ & $\ldots \ldots$ \\
\hline$r$ & $p_{\mathrm{r} 1}$ & $p_{\mathrm{r} 2}$ & $\ldots \ldots$ & $p_{\mathrm{rc}}$ & $p_{\mathrm{r} \bullet}$ \\
\hline Total & $p_{\bullet 1}$ & $p_{.2}$ & $\ldots \ldots$ & $p_{\text {oc }}$ & $p$ \\
\hline
\end{tabular}

Table 2: Cell Probabilities 
Table 3: Calculation Regression of Climate Factor and Natural Disaster in Rural Development Index

\begin{tabular}{|c|c|c|c|c|c|c|c|c|}
\hline Indicators & Model 1 & Model 2 & Model 3 & Model 4 & Model 5 & Model 6 & Model 7 & Model 8 \\
\hline$(1)$ & $(2)$ & $(3)$ & $(4)$ & $(5)$ & $(6)$ & $(7)$ & $(8)$ & (9) \\
\hline \multirow[t]{2}{*}{ Rainfall } & $0.042^{* * *}$ & $0.041^{* * *}$ & $0.041^{* \star \star}$ & $0.021^{* * *}$ & $0.021^{* \star *}$ & $0.021^{* \star \star}$ & $0.020^{* * *}$ & $0.019^{* \star *}$ \\
\hline & $(0.001)$ & $(0.001)$ & $(0.001)$ & $(0.001)$ & $(0.001)$ & $(0.001)$ & $(0.001)$ & $(0.001)$ \\
\hline \multirow[t]{2}{*}{ Wind speed } & $0.533^{* * *}$ & $0.556^{* * *}$ & $0.556^{\star \star \star}$ & $0.464^{* * *}$ & $0.459^{* * *}$ & $0.446^{\star \star \star}$ & $0.442^{* * *}$ & $0.444^{* * *}$ \\
\hline & $(0.019)$ & $(0.019)$ & $(0.019)$ & $(0.018)$ & $(0.018)$ & $(0.018)$ & $(0.018)$ & $(0.018)$ \\
\hline \multirow[t]{2}{*}{ Humidity } & $-2.141^{\star * *}$ & $-2.139^{* * *}$ & $-2.138^{\star * *}$ & $-1.490^{* * *}$ & $-1.488^{* * *}$ & $-1.488^{* * *}$ & $-1.503^{* * *}$ & $-1.468^{* * *}$ \\
\hline & $(0.032)$ & $(0.032)$ & $(0.032)$ & $(0.033)$ & $(0.033)$ & $(0.033)$ & $(0.032)$ & $(0.033)$ \\
\hline \multirow[t]{2}{*}{ Temperature } & $-8.715^{\star * *}$ & $-9.217^{* * *}$ & $-9.216^{* * *}$ & $-7.489^{* * *}$ & $-7.399^{* * *}$ & $-7.215^{* * *}$ & $-7.759^{* * *}$ & $-7.712^{* * *}$ \\
\hline & $(0.203)$ & $(0.206)$ & $(0.206)$ & $(0.198)$ & $(0.199)$ & $(0.200)$ & $(0.204)$ & $(0.204)$ \\
\hline \multirow[t]{2}{*}{ Air pressure } & $0.226^{* * *}$ & $0.248^{* * *}$ & $0.248^{* * *}$ & $0.195^{* * *}$ & $0.191^{* * *}$ & $0.184^{* * *}$ & $0.204^{* * *}$ & $0.202^{* * *}$ \\
\hline & $(0.008)$ & $(0.008)$ & $(0.008)$ & $(0.008)$ & $(0.008)$ & $(0.008)$ & $(0.008)$ & $(0.008)$ \\
\hline \multirow[t]{2}{*}{$\begin{array}{l}\text { Duration of } \\
\text { sunshine }\end{array}$} & $-0.169^{\star \star \star}$ & $-0.166^{\star * \star}$ & $-0.165^{\star * *}$ & 0.010 & 0.009 & $0.013^{*}$ & $0.063^{* * *}$ & $0.075^{* * *}$ \\
\hline & $(0.007)$ & $(0.007)$ & $(0.007)$ & $(0.007)$ & $(0.007)$ & $(0.007)$ & $(0.008)$ & $(0.008)$ \\
\hline \multirow[t]{2}{*}{ Burning fields } & $-4.043^{* * *}$ & $-3.925^{\star * *}$ & $-3.931^{* * *}$ & $-2.460^{\star * *}$ & $-2.443^{* * *}$ & $-2.399^{* * *}$ & $-2.510^{* * *}$ & $-2.460^{* * *}$ \\
\hline & $(0.103)$ & $(0.104)$ & $(0.104)$ & $(0.102)$ & $(0.102)$ & $(0.102)$ & $(0.102)$ & $(0.102)$ \\
\hline \multirow[t]{2}{*}{ Excavation sites } & $0.320^{\star * *}$ & $0.446^{* * *}$ & $0.440^{* * *}$ & $0.667^{* \star *}$ & $0.664^{* \star *}$ & $0.671^{* * *}$ & $0.551^{* \star *}$ & $0.549^{* * *}$ \\
\hline & $(0.094)$ & $(0.094)$ & $(0.094)$ & $(0.092)$ & $(0.092)$ & $(0.092)$ & $(0.092)$ & $(0.092)$ \\
\hline \multirow[t]{2}{*}{$\begin{array}{l}\text { Warnings of } \\
\text { natural disasters }\end{array}$} & $1.940^{* * *}$ & $2.017^{* \star *}$ & $2.029^{* * *}$ & $1.130^{* \star *}$ & $1.131^{* * *}$ & $1.104^{* * *}$ & $1.096^{* * *}$ & $1.083^{* * *}$ \\
\hline & $(0.144)$ & $(0.144)$ & $(0.144)$ & $(0.136)$ & $(0.136)$ & $(0.136)$ & $(0.137)$ & $(0.136)$ \\
\hline \multirow[t]{2}{*}{ Floods } & $1.882^{* * *}$ & $1.845^{\star \star *}$ & $1.838^{* * *}$ & $1.554^{* \star *}$ & $1.573^{\star \star *}$ & $1.584^{* * *}$ & $1.555^{\star \star \star}$ & $1.557^{* * *}$ \\
\hline & $(0.098)$ & $(0.097)$ & $(0.097)$ & $(0.095)$ & $(0.095)$ & $(0.095)$ & $(0.095)$ & $(0.095)$ \\
\hline \multirow[t]{2}{*}{ Flash floods } & $0.854^{* * *}$ & $0.895^{\star \star \star *}$ & $0.895^{\star \star \star *}$ & $0.945^{\star \star *}$ & $0.933^{* \star *}$ & $0.864^{* * *}$ & $0.849^{* \star \star}$ & $0.858^{\star \star \star}$ \\
\hline & $(0.287)$ & $(0.287)$ & $(0.287)$ & $(0.280)$ & $(0.280)$ & $(0.280)$ & $(0.281)$ & $(0.281)$ \\
\hline \multirow[t]{2}{*}{ Earthquakes } & $-2.995^{\star \star *}$ & $-2.965^{\star * *}$ & $-2.960^{\star \star *}$ & $-2.432^{\star * *}$ & $-2.436^{\star * *}$ & $-2.577^{* * *}$ & $-2.442^{\star * *}$ & $-2.427^{\star \star *}$ \\
\hline & $(0.197)$ & $(0.197)$ & $(0.197)$ & $(0.189)$ & $(0.189)$ & $(0.188)$ & $(0.188)$ & $(0.187)$ \\
\hline \multirow[t]{2}{*}{ Whirlwinds } & $1.374^{* * *}$ & $1.448^{* * *}$ & $1.447^{* \star \star}$ & $1.263^{* * *}$ & $1.255^{\star \star \star}$ & $1.247^{* * *}$ & $1.208^{* * *}$ & $1.208^{\star \star *}$ \\
\hline & $(0.136)$ & $(0.136)$ & $(0.136)$ & $(0.131)$ & $(0.131)$ & $(0.131)$ & $(0.131)$ & $(0.131)$ \\
\hline \multirow[t]{2}{*}{ Volcanoes } & $2.457^{* * *}$ & $2.390^{* * *}$ & $2.405^{* * *}$ & $1.753^{* * *}$ & $1.703^{* * *}$ & $1.485^{\star \star *}$ & $0.881^{*}$ & $1.047^{* *}$ \\
\hline & $(0.509)$ & $(0.508)$ & $(0.508)$ & $(0.499)$ & $(0.499)$ & $(0.510)$ & $(0.506)$ & $(0.510)$ \\
\hline \multirow[t]{2}{*}{$\begin{array}{l}\text { Bordered by the } \\
\text { sea }\end{array}$} & & $-1.796^{* * *}$ & $-2.138^{\star * *}$ & $-1.074^{* * *}$ & $-1.058^{* * *}$ & $-1.123^{* \star *}$ & $-1.322^{* * *}$ & $-1.406^{* * *}$ \\
\hline & & $(0.124)$ & $(0.169)$ & $(0.167)$ & $(0.167)$ & $(0.166)$ & $(0.167)$ & $(0.166)$ \\
\hline \multirow[t]{2}{*}{$\begin{array}{l}\text { Has mangrove } \\
\text { forests }\end{array}$} & & & $0.667^{* * *}$ & $0.638^{* * *}$ & $0.662^{* * *}$ & $0.733^{* * *}$ & $0.605^{* * *}$ & $0.584^{* \star *}$ \\
\hline & & & $(0.220)$ & $(0.218)$ & $(0.218)$ & $(0.218)$ & $(0.219)$ & $(0.218)$ \\
\hline $\begin{array}{l}\text { Underdeveloped } \\
\text { areas }\end{array}$ & & & & $-8.357^{\star \star *}$ & $-8.386^{\star * *}$ & $-8.340^{\star * *}$ & $-8.724^{\star \star *}$ & $-8.980^{\star \star *}$ \\
\hline
\end{tabular}




\begin{tabular}{|c|c|c|c|c|c|c|c|c|}
\hline Indicators & Model 1 & Model 2 & Model 3 & Model 4 & Model 5 & Model 6 & Model 7 & Model 8 \\
\hline & & & & $(0.127)$ & $(0.127)$ & $(0.127)$ & $(0.134)$ & $(0.136)$ \\
\hline \multirow[t]{2}{*}{ GRDP per capita } & & & & & $-0.267^{\star \star}$ & $-0.417^{* * *}$ & $-0.506^{* * *}$ & $-0.470^{* * *}$ \\
\hline & & & & & $(0.114)$ & $(0.115)$ & $(0.115)$ & $(0.115)$ \\
\hline \multirow[t]{2}{*}{ Regional status } & & & & & & $3.437^{* * *}$ & $3.263^{* * *}$ & $3.348^{* * *}$ \\
\hline & & & & & & $(0.328)$ & $(0.336)$ & $(0.335)$ \\
\hline \multirow[t]{2}{*}{$\begin{array}{l}\text { Province that is } \\
\text { crossed by the } \\
\text { equator }\end{array}$} & & & & & & & $1.924^{* * *}$ & $1.690^{\star * *}$ \\
\hline & & & & & & & $(0.138)$ & $(0.140)$ \\
\hline \multirow[t]{2}{*}{$\begin{array}{l}\text { Regency/ } \\
\text { municipality that } \\
\text { is crossed by the } \\
\text { equator }\end{array}$} & & & & & & & & $3.189^{\star \star *}$ \\
\hline & & & & & & & & $(0.329)$ \\
\hline \multirow[t]{2}{*}{ Constant } & $233.952^{* * *}$ & $225.132^{* * *}$ & $225.034^{* * *}$ & $176.521^{* * *}$ & $177.609^{* * *}$ & $180.047^{* * *}$ & $172.542^{* * *}$ & $169.903^{* * *}$ \\
\hline & $(2.342)$ & $(2.410)$ & $(2.410)$ & $(2.406)$ & $(2.475)$ & $(2.476)$ & $(2.558)$ & $(2.556)$ \\
\hline Observed & 72,333 & 72,333 & 72,333 & 72,333 & 72,333 & 72,333 & 72,333 & 72,333 \\
\hline R-squared & 0.265 & 0.267 & 0.267 & 0.324 & 0.325 & 0.326 & 0.328 & 0.329 \\
\hline
\end{tabular}

\section{Results}

Before entering the control variable, the R-squared value is 26.50 percent and increases to 32.90 percent when interacting with seven control variables (see Table 3). From the models formed, it is known that the more control variables involved, the better the strength of the model. This is consistent with the results of the study put forward by Atinc and Croll (2012). Underdeveloped area indicators have the greatest impact when included in the model.

Overall, the model has the same direction when before and after the control variable is entered (see Figure 1). Temperature and underdeveloped area indicators have the greatest constants when compared to other indicators, while rainfall is the smallest indicator on the model. Of the overall models and indicators there is only one indicator that is not significant, namely, duration of sunshine in model 4 and model 5.

When viewed through climate variables, it is known that temperature has the greatest role in rural development. The second big negative response can be seen from the air pressure indicator, where each positive increase in temperature and humidity will negatively impact rural development in the range of 10 points. The other four climate indicators have relatively the same coefficients. When viewed through the disaster variable, it is known that earthquake and flood indicators have the greatest impact. However, the coefficients on these variables have the opposite direction. The other three disaster variables have relatively similar coefficients. When viewed through community behavior variables, it is known that burning of fields and warning of natural disasters have the greatest impact. However, the coefficients on these variables have the opposite direction. The excavation site variable has a positive coefficient (see Table 4).

Through the CHAID analysis it is known that the highest ranking of the eight models includes indicators of rainfall, wind speed, humidity, temperature, air pressure, duration of sunshine, people's behavior in burning fields, and the status of underdeveloped areas. The status of underdeveloped areas and duration of sunshine make a very large contribution in the model, because they always have a big role compared to other observational indicators. Conversely, disaster variable is not a significant variable in the priority cluster.

Data shows that climate has the largest composition in rural development, which can be seen from the cumulative value of splitting variable permutation importance (see Figure 2). In cluster 1 analysis, most of the climatic factors made a large contribution followed by regional indicators. Territorial indicators are only dominated by the role of underdeveloped areas indicators. The community behavior variable has a very small role in the model. Indicators of community behavior that have a role are indicators of burning fields and warning of natural disasters. 


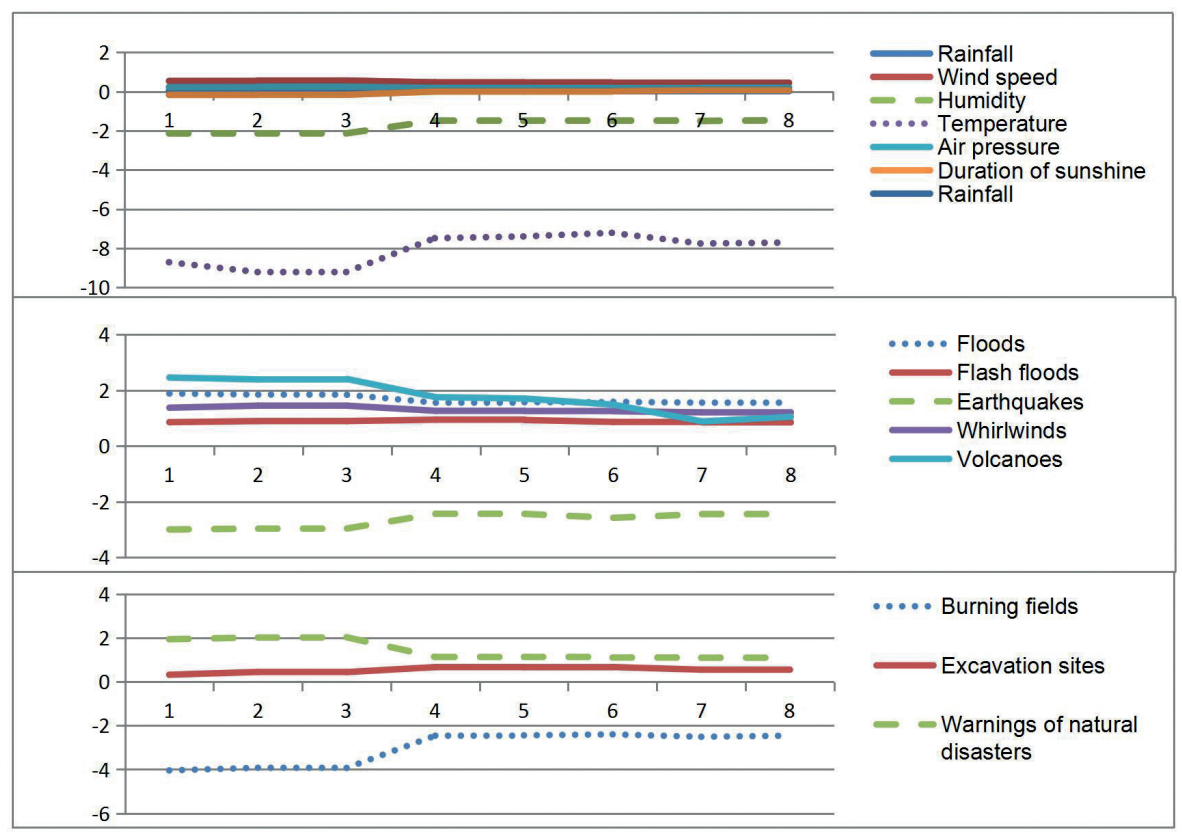

Figure 1: Comparison of Coefficients According to Model and Observation Factors

Table 4: Ranking of Variables Based on CHAID Calculation of Climate and Disaster Factors in Rural Development

\begin{tabular}{|c|c|c|c|c|c|c|c|c|}
\hline Indicators & Model 1 & Model 2 & Model 3 & Model 4 & Model 5 & Model 6 & Model 7 & Model 8 \\
\hline (1) & (2) & (3) & (4) & (5) & (6) & $(7)$ & (8) & (9) \\
\hline Rainfall & (1) & (2) & (3) & (3) & (3) & (6) & (5) & (4) \\
\hline Wind speed & $(7)$ & (3) & $(2)$ & (4) & $(5)$ & (4) & $(4)$ & (5) \\
\hline Humidity & $(2)$ & (5) & (11) & (7) & $(7)$ & (8) & (9) & (8) \\
\hline Temperature & (6) & & $(8)$ & (6) & (6) & (5) & (6) & (6) \\
\hline Air pressure & (5) & (4) & (4) & (5) & $(4)$ & (3) & (3) & (3) \\
\hline Duration of sunshine & (3) & (1) & $(1)$ & (2) & $(2)$ & (1) & $(1)$ & (2) \\
\hline Burning fields & $(4)$ & $(6)$ & $(5)$ & $(8)$ & $(8)$ & $(7)$ & $(8)$ & \\
\hline Excavation sites & (9) & (11) & (12) & (12) & (13) & (13) & & \\
\hline Warnings of natural disasters & (13) & $(12)$ & (13) & (13) & (14) & $(16)$ & & \\
\hline Floods & $(8)$ & $(8)$ & $(7)$ & $(10)$ & $(12)$ & (15) & & \\
\hline Flash floods & (14) & & & $(17)$ & & & & \\
\hline Earthquakes & (12) & $(13)$ & (14) & (11) & $(11)$ & $(11)$ & $(12)$ & \\
\hline Whirlwinds & (11) & $(10)$ & (9) & $(14)$ & (15) & & & \\
\hline Volcanoes & $(10)$ & $(9)$ & $(10)$ & $(15)$ & $(16)$ & $(14)$ & & \\
\hline Bordered by the sea & & $(7)$ & $(6)$ & $(9)$ & $(9)$ & $(9)$ & (11) & \\
\hline Has mangrove forests & & & & $(16)$ & $(17)$ & $(17)$ & & \\
\hline Underdeveloped areas & & & & $(1)$ & (1) & $(2)$ & $(2)$ & (1) \\
\hline GRDP per capita & & & & & (10) & (12) & & \\
\hline Regional status & & & & & & $(10)$ & (10) & (9) \\
\hline $\begin{array}{l}\text { Province that is crossed by the } \\
\text { equator }\end{array}$ & & & & & & & $(7)$ & (7) \\
\hline $\begin{array}{l}\text { Regency/municipality that is } \\
\text { crossed by the equator }\end{array}$ & & & & & & & & \\
\hline
\end{tabular}




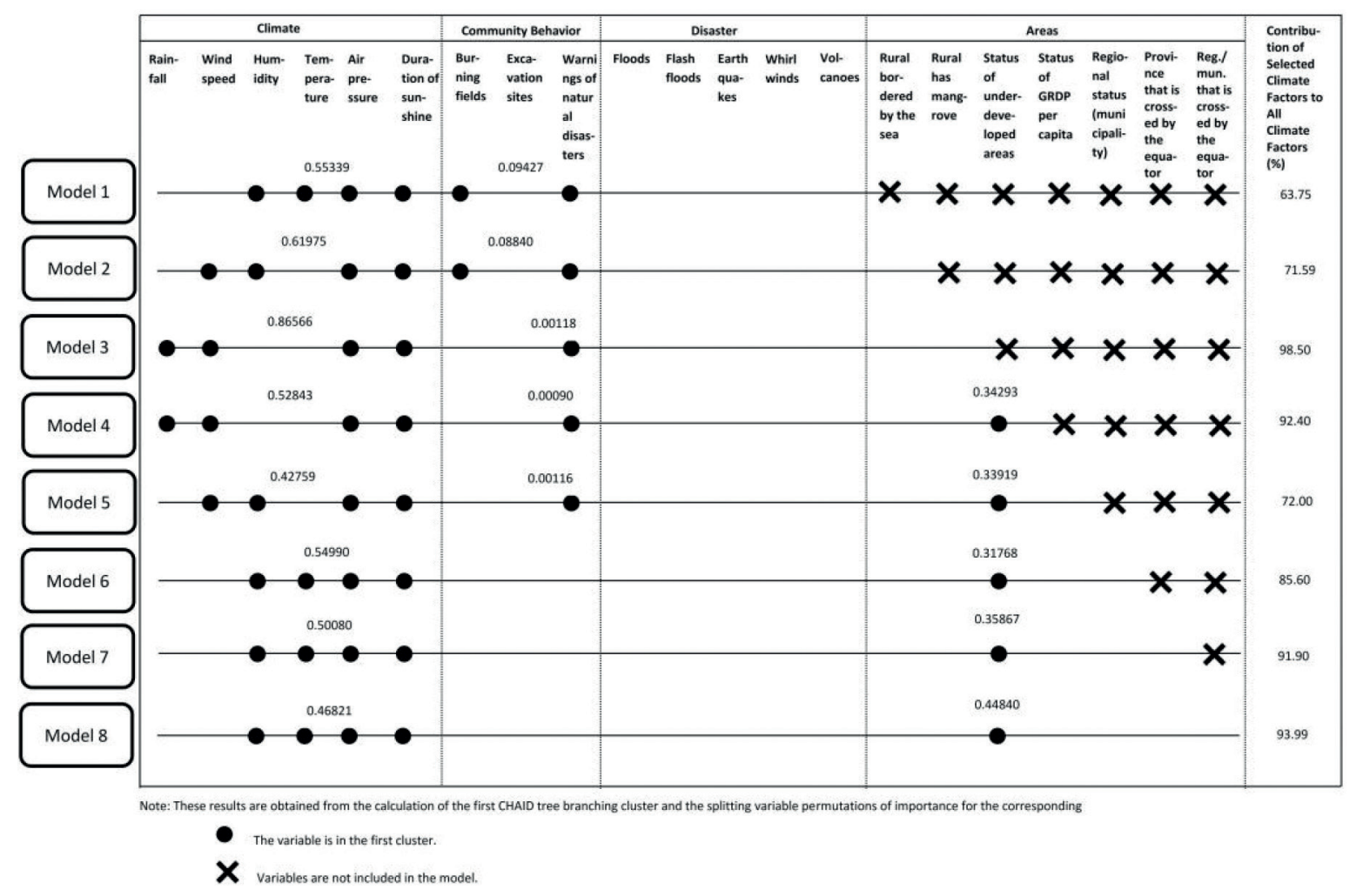

Figure 2: Calculation of Priority Clusters

The culture of burning fields by farmers when they want to open new agricultural land becomes a negative factor in the formation of the rural development index. This is clearly felt when such practices are done; it means that the local community is still relatively low in terms of knowledge. On the other hand, natural disaster warnings implemented in rural areas will have a positive impact on rural development. A rural area that has implemented a disaster warning means that the rural area has considered the adverse effects when a disaster occurs there. This anticipation is very positive, because the rural area will have minimal impact in the event of a natural disaster. In addition, the aspect of disaster mitigation is the result of developing the mind and cooperation of the community and rural officials. Indirectly, this factor will contribute positively to rural development.

If seen from the role of selected climate factors in cluster 1 against all indicators on climate factors, data shows that selected climate indicators have a role in the range of 63.75 - 97.50 percent in the overall model, whereas in model 3 these selected climate indicators play a very big role on overall climate factors. This indicates that in model 3 , the combination of four indicators can make a major contribution to the model built.

\section{Discussion}

Climate, disaster and community behavior are important factors in rural development. Climate is a natural phenomenon that cannot be denied. However, climate phenomena can be controlled before worse impacts will occur. Climate change has been felt by all countries in various parts of the world, and will have a negative impact on human life if it is not accompanied by good mitigating measured. Bad climate is often followed by natural disasters. The community will certainly respond to the series of conditions to survive. However, unwittingly, people's behavior actually aggravates the state of the environment. The set of observational variables will accumulate into community development, which at the smallest level will be reflected in rural communities.

From the results of the calculation of regression analysis, with or without control variables, it is known that all variables have a significant effect. Climate variables have a large role on humidity and temperature indicators. Humidity and high temperatures will cause low rural development. Humidity and temperature are two contradictory conditions - when the temperature rises, humidity will fall. From this phenomenon it can be concluded that the development will progress when a rural area has a temperature that is not high, but not too humid too. 
The impact of natural disasters on rural development has both positive and negative impacts. Disasters that have a negative impact on rural development in the future are earthquake disasters. This indicates that the earthquake disaster will still have a negative impact in the next 4 to 6 years (long-term) on rural development. This contrasts with other disaster indicators observed that have a positive impact. This is due to the role of the government and local communities who are swift to rebuild after a natural disaster, so that development will be created in the short term.

Based on research conducted by OECD (2016), development policies need to consider effectiveness and efficiency. The climate variables that need to be the focus of the government are indicators of solar radiation and air pressure. Whereas on community behavior, the government can focus on clearing community land through burning fields and promoting natural disaster warnings, especially in rural areas prone to natural disasters. Looking at territorial variables, it is right that the government has lately focused development efforts on underdeveloped areas.

This research indicates that community and government participation is needed to develop rural areas. From climate factors, rural areas need to anticipate, especially if they are vulnerable to rural extreme climate and natural disasters. In addition, rural areas need to appeal to people who carry out economic activities that will indirectly harm the environment, such as mining in green areas. If all goes well, surely an increase in rural development will be created.

\section{Conclusion}

Issues of global warming will affect climate change and will certainly have an impact on all aspects of life (Shahzad, 2015). On the other hand, the problem of community behavior and disaster aspects also play a role in people's lives. The results of the study show that these factors make a significant contribution to rural development. Community and government participation is needed as an anticipatory measure as these factors have a direct or indirect impact. In implementing policies policymakers must faced several constraints, including time, budget, and human resources. So, the main steps need to be taken to run an effective and efficient policy. Based on this research, the government needs to pay attention to rural areas that have high sun exposure, to culture natural disaster warnings, especially in areas prone to natural disasters, and it need to focus on underdeveloped areas. This study uses climate data at the provincial level, future studies should use climate data at the rural level to obtain more representative results.

\section{References}

Abid, M., Schneider, U. A., \& Scheffran, J. (2016). Adaptation to climate change and its impacts on food productivity and crop income: Perspectives of farmers in rural Pakistan. Journal of Rural Studies, 47, 254-266. doi:10.1016/j.jrurstud.2016.08.005

Aronsson, T., \& Schöb, R. (2018). Climate change and psychological adaptation: A behavioral environmental economics approach. Journal of Behavioral and Experimental Economics, 74, 79-84. doi:10.1016/j.socec.2018.03.005

Atinc, G., Simmering, M. J., \& Kroll, M. J. (2011). Control Variable Use and Reporting in Macro and Micro Management Research. Organizational Research Methods, 15(1), 57-74. doi:10.1177/1094428110397773

Austin, E. K., Rich, J. L., Kiem, A. S., Handley, T., Perkins, D., \& Kelly, B. J. (2020). Concerns about climate change among rural residents in Australia. Journal of Rural Studies, 75, 98-109. doi:10.1016/j.jrurstud.2020.01.010

Banerjee, D., \& Hysjulien, L. V. (2018). Understanding food disasters and food traumas in the global food system: A conceptual framework. Journal of Rural Studies, 61, 155-161. doi:10.1016/j.jrurstud.2018.04.011

Barbier, E. B., \& Hochard, J. P. (2018). The Impacts of Climate Change on the Poor in Disadvantaged Regions. Review of Environmental Economics and Policy, 12(1), 26-47. doi:10.1093/reep/rex023

Berdegué, J. A., \& Soloaga, I. (2018). Small and medium cities and development of Mexican rural areas. World Development, 107, 277-288. doi:10.1016/j.worlddev.2018.02.007

Bergholt, D., \& Lujala, P. (2012). Climate-related natural disasters, economic growth, and armed civil conflict. Journal of Peace Research, 49(1), 147-162. doi:10.1177/0022343311426167

Biegańska, J., Środa-Murawska, S., Kruzmetra, Z., \& Swiaczny, F. (2018). Peri-Urban Development as a Significant Rural Development Trend. Quaestiones Geographicae, 37(2), 125-140. doi:10.2478/quageo-2018-0019

BPS. (2018). Village Development Index. Jakarta, Indonesia: BPS. Retrieved July 03, 2020, from: https://www.bps.go.id/ publication/2019/05/09/4edae4bd6c18d24b1b4273fe/indekspembangunan-desa-2018.html. [Indonesian]

Bronfman, N. C., Cisternas, P. C., Repetto, P. B., \& Castañeda, J. V. (2019). Natural disaster preparedness in a multi-hazard environment: Characterizing the sociodemographic profile of those better (worse) prepared. Plos One, 14(4). doi:10.1371/ journal.pone.0214249

Castells-Quintana, D., Lopez-Uribe, M. D., \& Mcdermott, T. K. (2018). Adaptation to climate change: A review through a development economics lens. World Development, 104, 183-196. doi:10.1016/j.worlddev.2017.11.016

Chriest, A., \& Niles, M. (2018). The role of community social capital for food security following an extreme weather event. Journal of Rural Studies, 64, 80-90. doi:10.1016/j.jrurstud.2018.09.019 
Deligne, N. I., Horspool, N., Canessa, S., Matcham, I., Williams, G. T., Wilson, G., \& Wilson, T. M. (2017). Evaluating the impacts of volcanic eruptions using RiskScape. Journal of Applied Volcanology, 6(1). doi:10.1186/s13617-017-0069-2

Falco, C., Galeotti, M., \& Olper, A. (2019). Climate change and migration: Is agriculture the main channel? Global Environmental Change, 59, 101995. doi:10.1016/j. gloenvcha.2019.101995

Fang, Y., Zhu, F., Qiu, X., \& Zhao, S. (2018). Effects of natural disasters on livelihood resilience of rural residents in Sichuan. Habitat International, 76, 19-28. doi:10.1016/j. habitatint.2018.05.004

Faradiba, F. (2018). Forecasting Rainfall and Area of Plant Pest Disturbance in Bogor Regency. Pro Life, 5(3), 688-699. Retrieved July 03, 2020, from: http://ejournal.uki.ac.id/index. php/prolife/article/view/847/685

Filho, W. L., Ha'apio, M. O., Lütz, J. M., \& Li, C. (2020). Climate change adaptation as a development challenge to small Island states: A case study from the Solomon Islands. Environmental Science \& Policy, 107, 179-187. doi:10.1016/j. envsci.2020.03.008

Gallagher, C. A., Monroe, H. M., \& Fish, J. L. (2000). An iterative approach to classification analysis. Retrieved July 03, 2020, from: https://www.casact.org/pubs/dpp/dpp90/90dpp237.pdf.

Gatto, M., Wollni, M., Asnawi, R., \& Qaim, M. (2017). Oil Palm Boom, Contract Farming, and Rural Economic Development: Village-Level Evidence from Indonesia. World Development, 95, 127-140. doi:10.1016/j.worlddev.2017.02.013

Han, S., Tang, Q., Zhang, X., Xu, D., \& Kou, L. (2016). Surface wind observations affected by agricultural development over Northwest China. Environmental Research Letters, 11(5), 054014. doi:10.1088/1748-9326/11/5/054014

Hulme, D., \& Turner, M. M. (1990). Sociology and development: Theories, policies and practices. New York, NY: Harvester Wheatsheaf.

Iek, M., \& Blesia, J. U. (2019). Development Inequalities in Autonomous Regions: A Study Pre-and Post- Special Autonomy in Indonesia's Most Eastern Provinces. Journal of Asian Finance, Economics and Business, 6(1), 303-314. doi:10.13106/jafeb.2019.vol6.no1.303

Imperiale, A. J., \& Vanclay, F. (2016). Experiencing local community resilience in action: Learning from post-disaster communities. Journal of Rural Studies, 47, 204-219. doi:10.1016/j.jrurstud.2016.08.002

Jackson, G., Mcnamara, K. E., \& Witt, B. (2020). "System of hunger": Understanding causal disaster vulnerability of indigenous food systems. Journal of Rural Studies, 73, 163-175. doi:10.1016/j.jrurstud.2019.10.042

Javed, S. A., Haider, A., \& Nawaz, M. (2020). How agricultural practices managing market risk get attributed to climate change? Quasi-experiment evidence. Journal of Rural Studies, 73, 46-55. doi:10.1016/j.jrurstud.2019.11.020
Jha, S. K., Mishra, S., Sinha, B., Alatalo, J. M., \& Pandey, R. (2017). Rural development program in tribal region: A protocol for adaptation and addressing climate change vulnerability. Journal of Rural Studies, 51, 151-157. doi:10.1016/j. jrurstud.2017.02.013

Jiang, W., Deng, Y., Tang, Z., Cao, R., Chen, Z., \& Jia, K. (2016). Adaptive capacity of mountainous rural communities under restructuring to geological disasters: The case of Yunnan Province. Journal of Rural Studies, 47, 622-629. doi:10.1016/j. jrurstud.2016.05.002

Juhola, S., Klein, N., Käyhkö, J., \& Neset, T. S. (2017). Climate change transformations in Nordic agriculture? Journal of Rural Studies, 51, 28-36. doi:10.1016/j.jrurstud.2017.01.013

Kiryluk-Dryjska, E., Beba, P., \& Poczta, W. (2020). Local determinants of the Common Agricultural Policy rural development funds' distribution in Poland and their spatial implications. Journal of Rural Studies, 74, 201-209. doi:10.1016/j.jrurstud.2020.01.018

Krawchenko, T., Keefe, J., Manuel, P., \& Rapaport, E. (2016). Coastal climate change, vulnerability and age friendly communities: Linking planning for climate change to the age friendly communities agenda. Journal of Rural Studies, 44, 55-62. doi:10.1016/j.jrurstud.2015.12.013

Li, J., Jia, L., Liu, Y., Yang, Y., \& Jiang, N. (2018). Measuring model of rural transformation development path in Fuping County of Beijing-Tianjin-Hebei region. Habitat International, 74, 48-56. doi:10.1016/j.habitatint.2018.03.012

Li, J., Wang, Z., Wu, X., Guo, S., \& Chen, X. (2020). Flash droughts in the Pearl River Basin, China: Observed characteristics and future changes. Science of the Total Environment, 707, 136074. doi:10.1016/j.scitotenv.2019.136074

Mancini, L., \& Sala, S. (2018). Social impact assessment in the mining sector: Review and comparison of indicators frameworks. Resources Policy, 57, 98-111. doi:10.1016/j. resourpol.2018.02.002

Moreno-Cruz, J. B., \& Smulders, S. (2017). Revisiting the economics of climate change: The role of geoengineering. Research in Economics, 71(2), 212-224. doi:10.1016/j. rie.2016.12.001

Narayan, D. (2002). Bonds and Bridges: Social Capital and Poverty. In: Jonathan Isham, Thomas Kelly, \& Sunder Ramaswamy (Eds.), Social Capital and Economic Development. Cheltenham, UK: Edward Elgar Publishing. doi:10.4337/9781781950388.00013

Nazir, M., Murdifin, I., Putra, A. H., Hamzah, N., \& Murfat, M. Z. (2020). Analysis of Economic Development Based on Environment Resources in the Mining Sector. Journal of Asian Finance, Economics and Business, 7(6), 133-143. doi:10.13106/jafeb.2020.vol7.no6.133

Nørgaard, H., \& Thuesen, A. A. (2020). Rural community development through competitions, prizes, and campaigns: The villagers' perspective. Journal of Rural Studies. [In Press] doi:10.1016/j.jrurstud.2020.03.006 
OECD. (2016). Enhancing public sector efficiency and effectiveness. In: OECD Economic Surveys: Czech Republic 2016. Paris, France: OECD Publishing. https://doi.org/10.1787/ eco_surveys-cze-2016-6-en.

Olayide, O. E., \& Alabi, T. (2018). Between rainfall and food poverty: Assessing vulnerability to climate change in an agricultural economy. Journal of Cleaner Production, 198, 1-10. doi:10.1016/j.jclepro.2018.06.221

Osborne, R., \& Evans, N. (2019). Friend or foe? UK farmers' relationships with the weather. Journal of Rural Studies, 72, 205-215. doi:10.1016/j.jrurstud.2019.10.028

Padli, J., Habibullah, M. S., \& Baharom, A. H. (2018). The impact of human development on natural disaster fatalities and damage: Panel data evidence. Economic ResearchEkonomska Istraživanja, 31(1), 1557-1573. doi:10.1080/1331 $677 x .2018 .1504689$

Puspasari, A., \& Koswara, A. Y. (2016). Directions for Developing Underdeveloped Villages in Bondowoso Regency Based on Social, Economic and Infrastructure Aspects. Jurnal Teknik ITS, 5(2). doi:10.12962/j23373539.v5i2.17833

Sadeka, S., Mohamad, M. S., \& Sarkar, M. S. (2020). Disaster experiences and preparedness of the Orang Asli Families in Tasik Chini of Malaysia: A conceptual framework towards building disaster resilient community. Progress in Disaster Science, 6, 100070. doi:10.1016/j.pdisas.2020.100070

Sapkota, P., Keenan, R. J., Paschen, J., \& Ojha, H. R. (2016). Social production of vulnerability to climate change in the rural middle hills of Nepal. Journal of Rural Studies, 48, 53-64. doi:10.1016/j.jrurstud.2016.09.007

Sarkodie, S. A., \& Strezov, V. (2019). Economic, social and governance adaptation readiness for mitigation of climate change vulnerability: Evidence from 192 countries. Science of the Total Environment, 656, 150-164. doi:10.1016/j. scitotenv.2018.11.349

Sawada, Y., \& Takasaki, Y. (2017). Natural Disaster, Poverty, and Development: An Introduction. World Development, 94, 2-15. doi:10.1016/j.worlddev.2016.12.035

Shahzad, U. (2015). Global Warming: Causes, Effects and Solutions. Durreesamin Journal, 1(4). Retrieved July 03, 2020 , from: https://www.researchgate.net/profile/Umair_Shahzad/ publication/316691239_Global_Warming_Causes_Effects_ and_Solutions/links/590ca678aca2722d185bff31/GlobalWarming-Causes-Effects-and-Solutions.pdf.

Sørensen, J. F. (2018). The importance of place-based, internal resources for the population development in small rural communities. Journal of Rural Studies, 59, 78-87. doi:10.1016/j. jrurstud.2018.01.011

Soubry, B., Sherren, K., \& Thornton, T. F. (2020). Are we taking farmers seriously? A review of the literature on farmer perceptions and climate change, 2007-2018. Journal of Rural Studies, 74, 210-222. doi:10.1016/j.jrurstud.2019.09.005
Sousa, K. D., Casanoves, F., Sellare, J., Ospina, A., Suchini, J. G., Aguilar, A., \& Mercado, L. (2018). How climate awareness influences farmers' adaptation decisions in Central America? Journal of Rural Studies, 64, 11-19. doi:10.1016/j. jrurstud.2018.09.018

Stern, N. (2018). Public economics as if time matters: Climate change and the dynamics of policy. Journal of Public Economics, 162, 4-17. doi:10.1016/j.jpubeco.2018.03.006

Stojcheska, A. M., Kotevska, A., Bogdanov, N., \& Nikolić, A. (2016). How do farmers respond to rural development policy challenges? Evidence from Macedonia, Serbia and Bosnia and Herzegovina. Land Use Policy, 59, 71-83. doi:10.1016/j. landusepol.2016.08.019

Straub, A. M., Gray, B. J., Ritchie, L. A., \& Gill, D. A. (2020). Cultivating disaster resilience in rural Oklahoma: Community disenfranchisement and relational aspects of social capital. Journal of Rural Studies, 73, 105-113. doi:10.1016/j. jrurstud.2019.12.010

Sulistyaningrum, E. (2017). The Impact of Earthquake on Child Test Score. Journal of Indonesian Economy and Business, 32(2), 104. doi:10.22146/jieb.28987

Tang, R., Wu, J., Ye, M., \& Liu, W. (2019). Impact of Economic Development Levels and Disaster Types on the Short-Term Macroeconomic Consequences of Natural Hazard-Induced Disasters in China. International Journal of Disaster Risk Science, 10(3), 371-385. doi:10.1007/s13753-019-00234-0

Tanure, T. M., Miyajima, D. N., Magalhães, A. S., Domingues, E. P., \& Carvalho, T. S. (2020). The Impacts of Climate Change on Agricultural Production, Land Use and Economy of the Legal Amazon Region between 2030 and 2049. EconomiA, 21(1), 73-90. doi:10.1016/j.econ.2020.04.001

Uthes, S., Li, F., \& Kelly, E. (2017). Does EU rural expenditure correspond to regional development needs? Land Use Policy, 60, 267-280. doi:10.1016/j.landusepol.2016.10.016

Walker, H. M., Culham, A., Fletcher, A. J., \& Reed, M. G. (2019). Social dimensions of climate hazards in rural communities of the global North: An intersectionality framework. Journal of Rural Studies, 72, 1-10. doi:10.1016/j.jrurstud.2019.09.012

Xie, Z., Zhang, F., Lun, F., Gao, Y., Ao, J., \& Zhou, J. (2020). Research on a diagnostic system of rural vitalization based on development elements in China. Land Use Policy, 92, 104421. doi:10.1016/j.landusepol.2019.104421

Xuan, V. N. (2020). Determinants of Investment Capital Size: A Case of Small and Medium-Sized Enterprises in Vietnam. Journal of Asian Finance, Economics and Business, 7(6), 19-27. doi:10.13106/jafeb.2020.vol7.no6.019

Zhang, D., \& Managi, S. (2020). Financial development, natural disasters, and economics of the Pacific small island states. Economic Analysis and Policy, 66, 168-181. doi:10.1016/j. eap.2020.04.003 